Bryld, at formålet med bogen også er at animere til udviklingen af en ny politisk vision som alternativ til de højreorienterede politiske vinde, der for tiden er dominerende i dansk politik. Han har dog ikke selv noget bud på en ny vision som alternativ til den borgerlige regerings politik. Man kan jo også spørge, om venstrefløjens problem virkelig er fraværet af en ny samfundsvision, eller om det snarere er, at vælgerne tvivler på at venstrefløjen kan magte nogle velkendte samfundsproblemer, f.eks. indenfor integrationsområdet.

Bogens stof er spændende, men Brylds stil kan forekomme en smule snakkende. Da der er tale om artikler, som delvis omhandler det samme emne, er der også en del gentagelser. Imidlertid vil artiklerne bestemt være interessante for den, der er interesseret $\mathrm{i}$ arbejderbevægelsens historie, og som ikke har det store forhåndskendskab til området.

Michael Jeppesen

\section{Skolastisk transcendentalfilosofi?}

Hannes Möble: Der Tractatus de Transcendentibus des Franciscus de Mayronis, Peeters 2004, 188 sider, € 40,-

Franciscus de Mayronis († ca. 1328) var blandt de studerende, som hørte Duns Scotus (ca. 1265-1308) i Paris i de første år af det fjortende århundrede. Duns Scotus artikulerede en ny metafysikforståelse, som dannede skole. Den scotistiske bevægelse var en meget udbredt filosofisk-teologisk retning $i$ den sene middelalder. Selv efter den moderne videnskabsforståelses gennembrud formåede scotismen at bevare sin integritet. I det syttende århundrede opnåede den sågar en ny blomstringstid, men var dog ligesom epokens andre skolastiske retninger så isoleret $\mathrm{i}$ forhold til den nye tids nye filosofi, at den nærmest helt og aldeles er undsluppet vor moderne filosofihistoriske bevidsthed. Blandt Duns Scotus' daværende elever var Franciscus de Mayronis en af de mest markante og virkningshistorisk vigtigste. En del af hans værker blev trykt og udgivet efter bogtrykkerkunstens opkomst i renæssancen, en anden del er kun overleveret $i$ middelalderlige afskrifter. Dertil hører det foreliggende skrift, som nu foreligger i en tekstkritisk, latinsk udgave, forsynet med en fyldig introduktion af udgiveren, Hannes Möhle, som tidligere har leveret bidrag til udforskningen af forskellige sider af Duns Scotus' tænkning.

Skriftet tager et emne op, som er af stor betydning for den scotistiske forståelse af metafysikken, transcendentalelæren. Duns Scotus kaldte metafysikken for den 'transcenderende videnskab', ikke fordi den handler om det transcendente qua det hinsides, men fordi den tager udgangspunkt $i$ den type begreber, som overskrider, transcenderer, alle andre, mere specielle begreber og 
altså finder anvendelse, førend det værende inddeles $\mathrm{i}$ de ti aristoteliske kategorier. Dermed kan ikke blot det værende som sådan, men også det uendelige værende, Gud, begribes med transcendentalerne. Denne lære findes behandlet flere steder i Duns Scotus' værk, men en udførlig, systematisk fremstilling findes ikke fra hans hånd. Franciscus de Mayronis' skrift er den første selvstændige, systematiske afhandling om transcendentalerne.

Afhandlingen indeholder otte artikler, som stiller og besvarer de væsentligste spørgsmål vedrørende transcendentalerne. Spørgsmålet, hvad man skal forstå ved et transcendentale, besvares med, at det ikke hører under et bestemt slægtsbegreb, og at det abstraherer fra alle kategoriale bestemmelser (art. 1). Det er kendetegnet ved ikke at kunne adskilles fra det, som det formalt befinder sig i, og ved ikke at være realt forskelligt fra sit fundament (art. 2). Transcendensen eller overskridelsen af det kategoriale har 4 grader, som svarer til 4 grader af overkategorial almenhed (art. 3). Ethvert transcendentale er et aldeles enkelt begreb, dvs. det kan ikke opløses $\mathrm{i}$ andre begreber eller formalbestemmelser (art. 4). Af denne enkelhed følger transcendentalernes oprindelige forskellighed, dvs. de kan ikke reduceres til hinanden (art. 5). Transcendentalerne kan ikke prædiceres 'hvadhedsligt', hvilket betyder, at ingenting kan defineres gennem dem (art. 6). Tilsvarende kan de ikke selv defineres eller bestemmes 'hvadhedsligt' gennem et begreb, som står over dem (art. 7). Endelig slås det fast, at de 6 transcendentaler, som er 'konvertible' med hinanden, og som vi også kender fra Thomas Aquinas, nemlig 'værende, ting, noget, en, god og sand', er realt identiske, men dog på en vis måde også forskellige (art. 8). Det sidste punkt giver anledning til en udførlig diskussion af forholdet mellem det værende og de øvrige transcendentaler, hvormed skriftet afsluttes.

Som man kan se af den første artikel, er forholdet til det kategoriale særligt vigtigt for forståelsen af transcendentaliteten. Udgiverens indledning kredser især om dette tema, som trænger sig på, fordi Franciscus de Mayronis på trods af den skarpe afgrænsning mellem det kategoriale $o g$ det transcendentale ender med at bestemme de enkelte kategorier som transcendentale begreber. Udgiveren forklarer denne overraskende vending gennem en i begyndelsen af det fjortende århundrede gængs skelnen mellem kategorierne forstået som reale bestemmelser ved tingene ( $\mathrm{fx}$ hvid) og som begrebsklasser ( $\mathrm{fx}$ kvalitet). Som begrebsklasser hører kategorierne til en anden orden end de reale bestemmelser. De er 'sekundære intentioner', der som forstandsmæssigt værende eller entia rationis kun tilkommer en vis realitet i kraft af deres forhold til det reale, som de betegner. Det afgørende er, at disse sekundære intentioner prædi- 
ceres på en anden måde end de reale bestemmelser. De prædiceres ikke 'hvadhedsligt' og lever i det hele taget op til de øvrige kriterier for det transcendentale. For den skolastiske metafysikforståelse er det afgørende, at metafysikken i modsætning til logikken er en realvidenskab, dvs. har med realt værende at gøre. Med sin forståelse af de kategoriale begrebsklassers og det forstandsmæssigt værendes realitet kan Franciscus holde fast ved metafysikkens bestemmelse som realvidenskab og samtidig begrunde en udvidelse af det transcendentale felt til også at omfatte det kategoriale og det forstandsmæssige. I denne udvidelse af det scotistiske begreb om den 'transcenderende videnskab' ser udgiveren et skridt i retning af Kants transcendentalfilosofi. Mellem Franciscus de Mayronis og Kant er dog endnu næsten et halvt årtusindes gennemtænkning af transcendentalelærens betydning for metafysikbegrebet. Franciscus' bidrag er måske et skridt på vejen til vejen ... til Kant.

Denne bog vil uden tvivl komme til at spille en vigtig rolle for udforskningen af både transcendentalfilosofiens middelalderlige forhistorie og - mere specielt - scotismens historie. Bogens umiddelbare målgruppe må nok findes inden for den specialiserede filosofihistoriske forskning, men det brede perspektiv i den middelalderlige transcendentalelære garanterer dens status som et centralt studieobjekt også i en videre, idéhistorisk sammenhæng. Udgiveren er i øvrigt medforfatter til artiklen om de transcendentale begreber i Historisches Wörterbuch der Philosopbie (bd. 10, opslagsord Transzendental III.), og $\mathrm{i}$ indledningen vil man finde flere af de dér næunte skolastiske kilder mere udførligt behandlet og citeret. Filosofihistoriens første selvstændige afhandling om transcendentalerne kunne være blevet gjort tilgængelig for et større publikum, hvis udgiveren havde forsynet den med en oversættelse, men man må dertil sige, at Franciscus de Mayronis' skolastiske latin faktisk hører til den lettere af slagsen. Desuden er det vel også på sin plads, at der udkommer bøger, som minder os om, hvad vi går glip af, hvis vi ikke tager os tid til at tilegne os de klassiske sprog.

Claus Asbjorn Andersen

\section{Fabrikkens idébistorie}

Håkon W. Andersen, Terje Borgersen, Thomas Brandt, Knut Ove Eliassen, Ola Svein Stugu, Audun Øfsti: Fabrikken. Spartacus Forlag, Oslo, 2004, 682 sider, no. Kr. 298,-

Hvad er om ikke den vigtigste, så dog den mest altgennemtrængende idé gennem de seneste 200 år? Et overraskende, men yderst intelligent bud kunne være: standardiserede dele. I dag er det en selvfølge, at vi kan få reservedele til alt, lige fra biler og fly til dørhængsler, men det var faktisk først i 1851, ved verdensudstillingen i 